\title{
4
}

\section{The English Civil War and the politics of economic statecraft}

The relationship between historical writing and the political and religious conflicts of the 1640s was a complex one. ${ }^{1}$ Historians of the period generally emphasised that their loyalty was to the 'truth' rather than to any particular faction or party. Hamon L'Estrange, for example, used the frontispiece to his The Reign of King Charles (1655) to claim that this was a work 'Faithfully and Impartially delivered'. 2 Similarly, in the preface to his Observations (1656), a detailed critique of L'Estrange's History, Peter Heylyn claimed to be writing 'with a minde free from love, or hatred, or any of those other affections, which pre-ingagements in a party doe possesse men with'. ${ }^{3}$ Thomas Fuller, meanwhile, defended his Church-History of Britain (1655) by observing that the work 'was so far from prostituting her Self to Mercenary Embraces, She did not at all Espouse any Particular Interest, but kept her self a Virgin'. ${ }^{4}$ In making such comments, authors were emphasising their adherence to a series of well-established ideas about the importance of impartiality in historical writing. Indeed, before stating his own commitment to 'Truth', the parliamentarian historian Thomas May noted that 'the use of History, and the just Rules for composure of it [had] been so well and fully described heretofore' that it was 'lost labour and a needlesse extention of the present work' to discuss them further. ${ }^{5}$

Authors were also aware, however, that writing in a time of conflict presented certain challenges. Civil wars served not only to divide people, but also historical source material and, as May observed, his own position in Parliament meant that his knowledge of Parliamentarian 'Councels' was better than that of Royalist ones. Moreover, May acknowledged that the nature of the subject he was 
to discuss made it difficult to avoid partiality and impossible 'to escape the suspition or censure of it'. ${ }^{6}$ A similar point was made by Fuller, who gave the first chapter of his Appeal of Iniured Innocence (1659) the title: 'That it is impossible for the Pen of any Historians writing in (as our's) a divided Age, to please all Parties'. ${ }^{7}$ The politically charged atmosphere in which history was written and read was also affected by the role that historical argument played in the period's ideological conflicts. As J. G. A. Pocock has argued:

what occurred was that belief in the antiquity of the common law encouraged belief in the existence of an ancient constitution, reference to which was constantly made, precedents, maxims and principles from which were constantly alleged $[\ldots]$; and discussion in these terms formed one of the century's chief modes of political argument. Parliamentary debates and pamphlet controversies involving the law or the constitution were almost invariably carried on either wholly or partially in terms of an appeal to the past made in this way. ${ }^{8}$

This ensured that history and politics became intertwined to the point where, in the words of David Norbrook, it was 'very hard to separate political debate $[\ldots]$ from debates about the true meaning of English history. ${ }^{9}$ To write history, therefore, was to enter into a public discussion concerning the relative rights of king, Parliament and people, and the position of the Church of England within English society.

From the 1640s onwards, historical accounts of James I came to be shaped by these considerations. The key issue to be decided was the relationship between the King's approach to government and established English constitutional practices. For historians critical of the Stuarts, James had rejected the constitution and instigated the chain of events that led to the Civil War. Those more sympathetic to the Scottish King argued that his conduct was broadly in line with that of his predecessors; the unrest that had occurred in the period was a product of the malign Puritan and republican factions who were later to dismantle the constitution and execute their monarch. Writers were, of course, acutely aware that a complex blend of political, legal and confessional concerns had been at stake in the various confrontations between Charles and his critics. Nevertheless, they saw that debate had frequently coalesced around issues concerning revenue, most significantly disagreements regarding the King's right to 'Tonnage and Poundage', his attempts to raise money through 
the forced loan of 1626 and 'Ship Money', and his various efforts to secure parliamentary subsidies. The origin of these conflicts, it was agreed, was to be found in the reign of James, whose struggles to raise money in the face of a recalcitrant Parliament prefigured those of his son. As a consequence, James's management of revenue became a highly politicised and divisive issue, which received detailed commentary from the period's historians. Indeed, Michael Sparke's The Narrative History of King James, for the first fourteen Years was published with 'An abstract or Brief Declaration of the Present State of his Majesties Revenew', a seventy-two-page list of 'all monies [James] brought into his [...] coffers' ${ }^{10}$ Commerce occupied a more complex position in the period. Discussions of James lack the detailed engagement with the commercial aspects of economic statecraft that, as we have seen, had been a feature of Jacobean writing. Equally, however, references to trade and tradesmen are frequent, and England's moral decay - a theme as important to Royalist writers anxious to 'explain' the Regicide, as it was to Parliamentarian authors seeking to condemn Stuart practices - was frequently presented as a process of commercialisation.

The main body of this chapter explores how these ideas were treated by the Civil War era historians Anthony Weldon, Arthur Wilson and William Sanderson. ${ }^{11}$ Each of the writers, it will be argued, despite their political differences, developed a moralistic analysis of James's financial management rooted in Livian ideas of exemplary virtue and honour. The final section of the discussion shows how these ideas were developed by the historian and political economist Roger Coke in the 1690s.

\section{Parliamentarian history: Anthony Weldon's Court and Character of King James}

Anthony Weldon's writing was shaped by his personal relationship with the King. ${ }^{12}$ In the first part of his career Weldon had served in James's Court, acting as both clerk of the green cloth and clerk of the kitchen. At some point during the later years of the King's reign, however, he lost these positions; some accounts have claimed that this was a result of a scurrilous description of Scotland that he wrote in 1617, while others have seen Weldon as a victim of reforms to the royal household introduced by Lionel Cranfield in the 1620s. 
What is clear, however, is that by the time of the Civil War, Weldon was an avowed opponent of the King. He served as the head of the parliamentary committee for Kent, and acquired a reputation - albeit possibly an undeserved one - for his autocratic and tyrannical management of the county.

Weldon died in 1648, and his The Court and Character of King James was published posthumously in 1650. The image of James that it presented was not a flattering one. Attention was drawn to the King's cowardice, his over-large tongue and his poor personal hygiene, and he emerges from the text as both a ludicrous figure and a repulsive one. ${ }^{13}$ Running alongside these highly personal attacks, however, was a more general narrative regarding the effects of Stuart government. For Weldon, James's reign had seen the emergence of a new and pernicious obsession with money. The origins of this development lay in the King's poor financial management and, more specifically, his violation of the core precepts of conventional Aristotelian ideas about liberality. Aristotle had argued that the liberal man was one who "will both give and spend the right amounts and on the right objects, alike in small things and in great, and that with pleasure; he will also take the right amounts and from the right sources'. ${ }^{14}$ While James could not be called mean, he had, in Weldon's view, spent both excessively and unwisely, wasting huge amounts of money on enriching unworthy individuals, primarily the 'beggarly' Scots and a series of undeserving favourites. ${ }^{15}$ Equally, the King had erred in his approach to the taking of money, drawing excessively on the purses of his subjects, and spending resources that were not his own. As Weldon observed, James would 'rather part with 100 li. hee never had in his keeping, then $[s i c]$ one twenty shillings peece within his owne custody'. ${ }^{16}$

The ultimate consequence of the King's failings was that financial concerns came to be prioritised over all other matters. As Weldon noted, 'ever since Queene Elizabeths death, the raysing money hath been the only way to raise men, as being held the essential property of a wise man, to know how to bring in money (per fas aut nefas)'. ${ }^{17}$ This idea was further emphasised by Weldon's attempt to associate the actions of James's primary political advisors and ministers with low and corrupt forms of mercantile activity. Thus Weldon described the struggle between Salisbury and Suffolk for the King's favour as a confrontation to decide 'who should ingrosse him, and make 
him their Monopoly'. ${ }^{18}$ Particularly vehement, meanwhile, were the attacks launched on the courtiers Lionel Cranfield and Sir Arthur Ingram. The former was the holder of a series of Court posts and, from 1621 to 1624, Lord Treasurer. The latter served as 'cofferer' of the king's household in 1615 . Weldon described them as

two meane fellowes grand Projectors, the one, Ingram, an ordinary Waiter of the Customes, the other, Cranfield, an Apprentice, who had served three broken Citizens, and it is probable by his wit and honesty he might thrive by the all, and lay that for his first a foundation of his future projecting. ${ }^{19}$

Such backgrounds, it was argued, rendered them fundamentally unsuitable for high office. As was observed in relation to Cranfield: '[he was an individual] whose minde was ever so base, as never to discerne what Honour was, nor ever had hee any other inherent Honour then what in his Apprenticeship he raked out of the Kennel'. ${ }^{20}$ Similar themes are also present in Weldon's discussion of the selling of honours. Salisbury, Weldon argued, had bought himself a position of power in the early days of James's reign. He then went on not only to teach the King 'how to enhance his [James's] Prerogative so above the Lawes, that he might inslave the Nation', but also successfully instigated a scheme for selling new 'Baronets'. ${ }^{21}$ Defending this idea to the King, Salisbury observed:

he [James] should finde his English Subjects like Asses, on whom he might lay any burthen, and should need neither Bit, nor Bridle, but their Asses eares; And when the King said, It would discontent the generality of the Gentry: He replyed, Tush Sir, you want the money, that will doe you good, the Honour will doe them very little; And by these courses he raised himselfe, friends, and family, to Offices, Honours, and great Possessions. ${ }^{22}$

The key implication of such comments was that 'honours', in becoming a commercial object freely available for purchase on the open market, had lost their fundamental honourableness. More generally, the corruption that England underwent during James's reign is imagined by Weldon as a process through which both statesmen and honour itself became commoditised and, as a consequence, morally compromised.

In making such comments Weldon employed a highly conventional anti-commercial rhetoric, which had received its most famous 
formulations in Aristotle's Politics and the work of Machiavelli. His position, however, is complicated by his claim that it was James's poor financial management that had brought about the decay of honour. Indeed, the effect of the King's dishonourable conduct is measured, in part, in financial terms. Thus, when discussing James's pacifism, Weldon noted that he 'had rather spend 100,000li. on Embassies, or to keep or procure peace with dishonour, then 10,000 li. on an Army that would have forced peace with honour'. ${ }^{23}$ As a result, his decisions were 'no less chargeable then dishonourable and unprofitable to him and his whole Kingdome'. ${ }^{24}$ The key consequence of the King's approach to finance, meanwhile, was to have 'enriched many in particular, as Salisbury, Suffolke, Northampton, Worcester, Lake \&c. yet [to have beggared] himself and the Nation in generall'. ${ }^{25}$ For Weldon, therefore, if the King had behaved in a more honourable manner, prioritising national interests over individual ones, both he and England would have benefited in financial terms.

\section{Parliamentarian history: Arthur Wilson's The History of Great}

\section{Britain}

A more detailed and scholarly account of James's reign was to emerge in Arthur Wilson's The History of Great Britain (1653). ${ }^{26}$ Before turning to history in the latter part of his life, Wilson had enjoyed a rich and varied career. ${ }^{27}$ Born in around 1595, he spent two years of his youth in France as the guest of wine merchant relatives. On his return to England, he eventually trained as an exchequer clerk, before entering the service of Robert Devereux, third Earl of Essex. He accompanied Essex to the Palatinate in 1620 and later saw military action as part of the campaign to restore Frederick V, the territory's deposed ruler, to his former throne. After leaving Essex's service in 1631, Wilson studied medicine at Trinity College, Oxford, and authored a series of plays, three of which found their way on to the London stage. Later he gained employment with Henry Rich, the Earl of Warwick, and both served under him in the wars in the Low Countries and acted as the steward of his estates when Warwick was fighting for Parliament. Wilson continued to write during this period, penning both his history and an autobiography, a work which, in line with Presbyterian beliefs, sought to trace the role played by 'Divine Goodnes' in shaping 'the many occurences of [...] life'. ${ }^{28}$ 
The History of Great Britain opened with a 'Proeme' in which Wilson confidently proclaimed his own impartiality. This work would, he noted, occupy a middle passage between the 'Scylla' of Weldon's angry attack on James and the 'Charybdis' of William Sanderson's hagiographic Aulicus Coquinarie (1651). However, while Wilson largely avoided the Court and Character's scurrility, his approach had a good deal more in common with Weldon's than Sanderson's. Indeed, the bulk of his introductory remarks were concerned with defending the right of the historian to criticise a monarch. This point, like many others in Weldon's ornately written account, was made through an extended metaphor. 'Histories', he argued, 'are like Anatomies, especially when they reflect on Persons.' 29 Crude attempts to 'hack, hew or bespatter' were to be avoided; rather a 'gentle hand' was required, which could work with 'Authority and Knowledge'. ${ }^{30}$ However, while neither history nor anatomy should 'cauterise, and slash with Malice', they both needed to be truthful in order to be useful. ${ }^{31}$ When tracing the ways and passages of the body in dissection, therefore, it was necessary to note 'where Obstructions have been, where Diseases have bred, and by this Pattern learn to remove the accrecion of bad Humours. ${ }^{32}$ Similarly, in history, 'Examples of basenesse, and unworthinesse, if truly and genuinely related, may deterr and hinder the violent Career of such as mind no other happinesse than what this vapour of vain-glory can contribute; and esteem a good Name more among men, than acceptance with God.' ${ }^{\prime 3}$ Such an approach to history had been widely endorsed in the past; Tacitus, for example, Wilson argued, was never blamed for 'personating Tiberius Dissimulation, Nero's Cruelty, Seianus Pride, [nor] Livia's and Messalina's Adulteries'. ${ }^{34}$ 'These times', however, were 'full of perplexed and disastrous Divisions', which ensured that any impartial work, his own included, was likely to face a series of impassioned criticisms. ${ }^{35}$

The key aim of the History of Great Britain was to explain the origins of such divisions. Its general argument was that in Jacobean England the 'sensitive faculties' had gained 'predominance over the Reasond', thereby producing an age of excess and vanity. ${ }^{36}$ James was in large part responsible for this state of affairs. His excessive generosity to favourites had fomented luxury and debauchery, and these, in turn, had undermined the dignity, popularity and financial security of the monarchy. Such developments were frequently presented as either 
literal or metaphorical processes of commercialisation. A particularly useful example of the latter approach comes in his general analysis of the role of the monarch. Wilson began by thinking about the movement of heavenly objects, noting that 'We see all the Motions of Superiour Bodies, in what excellent Order and Perfection they move. ${ }^{37}$ He went on to contrast two types of bodies. On the one hand, there are comets which, emitting 'grosse and putrid Matter', follow an unpredictable course, are auguries of 'Prodigious Calamities', and, after blazing a little, extinguish themselves. ${ }^{38}$ On the other hand, there are celestial bodies that beget no wonder [...] but keep a constant Course in their own Spheres, and are not contaminated with things below them, yet they retain a Powerfull Influence over them'. ${ }^{39}$ This latter type of body provides a good model, Wilson notes, for Princes who should 'shine in Glory'. ${ }^{40}$ However, he continued, when Princes

grovell here for trash and trumpery, and trade away that gallant stock of Love housed in their Peoples Hearts, for some false Coin, minted by Passion, mutable Affection, or mis-led Reason, they doe degrade themselves. And then the onely difference betwixt a King, and a mean Man, is, That the one, by his Trade, cosens a few; the other a great many, but himself most. ${ }^{41}$

A monarch's failure to perform his duties, therefore, is viewed - in metaphorical terms at least - as transforming him from a celestial object into a corrupt tradesman. Similar associations are at play in the History's main narrative. The disastrous state of James's revenue, it is noted, meant that he came to see Parliament not as a source of counsel, but rather of money. Consequently, he sought to make 'Merchandize of the Common-wealth' by conceiving of them as 'his Banke, his Merchants'. ${ }^{42}$ This attempt to treat politicians as tradesmen was based on a fundamental misunderstanding: 'Merchants looke for their money againe with advantage, and therefore their Counsell in disposing it may be well spared'. ${ }^{43}$ Parliament, however, 'if they raise money from the People (which is never to be repayed) there is good reason they should know not onely to what purpose it is levied, but how prudently and fitly laid out'. ${ }^{44}$ The logic of commerce, therefore, was not the logic of the constitution. Equally, those engaged in commercial and financial activities were not, at least in a well-run polity, statesmen. Indeed, Cranfield's tenure as Lord Chancellor was evidence of the Court's failings. This individual, 
who had been a Citizen of London, bred up in the Custome-house, and knowing the secret contrivances of those Officers, was thought fittest to manage the King's Revenue: For in expensive and wanting Courts, those great Officers are most acceptable, that by their finesses and projects, can bring in that, which with riot and prodigality goes out. ${ }^{45}$

For Wilson, therefore, poor financial management had helped to create an age of projects and projectors.

Such comments have a good deal in common with the analysis developed in Weldon's Court and Character. What separates Wilson from Weldon, however, is his account of the consequences of James's government. As we have seen, Weldon argued that James's gratuitous expenditure had served to impoverish the people of England, while his pacifism had sacrificed the interests of the nation in order to enrich a small group of corrupt courtiers. For Wilson, by contrast, peace had brought universal plenty, albeit a form of plenty that had undermined England's moral and political fabric. These ideas were developed through yet another analogy, this time between political and natural bodies. If a body is inactive and overfed, he argued, it will contract 'gross humors, which will have vent'. ${ }^{46}$ To maintain a healthy body, therefore, 'Exercise' is required to 'keep the spirits active, $[\ldots]$ digest the grosser and sulginous matter' and strengthen 'the Nervs of a Kingdom or Republique ${ }^{47}$ Such exercise could only be achieved through 'Warre', which, he argued, 'is necessary as Physicke for unsound Bodies. ${ }^{48}$ These assumptions led Wilson to present the King's pacifist foreign policy as a contagious, enervating force. It had, he observed, ensured that the Germans had 'swelled into a Dropsie of Voluptuousness, by Plenty, and the sweets of Peace', while France 'wanting Exercise' had become 'surfetted with diseases at home, which by fits broke out into Tumors among themselves'. ${ }^{49}$ In England 'bravery and feasting, the Parents of Debaucherie and Riot, flourished'. ${ }^{50}$ Such behaviour not only served to corrupt the populace, but also made the writing of history difficult. 'There is', Wilson contended,

no Theam for History when men spill more drink than blood; when plots and contrivances for Lust, acted in dark corners, are more practiced than Strategems in War, and when the Stages with silken Pageants and Poppets, that slacken the sinews, are more frequented than those Theaters of Honor, where Industry brawns and hardens the Armes. ${ }^{51}$ 
Perhaps more worryingly, peace also had the potential to breed civil discontent. 'Some', Wilson noted, compared James to Tiberius 'for Dissimulation'; however,

Peace was maintained by him as in the Time of Augustus; And Peace begot Plenty, and Plenty begot Ease and Wantonness, and Ease and Wantonnesse begot Poetry, and Poetry swelled to that bulk in his time, that it begot strange Monstrous Satyrs, against the King own person, that hauntrd [sic] both Court and Country. ${ }^{52}$

Wilson was unwilling to provide details of these 'satyrs', but switching to a horticultural metaphor, noted that the 'tongues' of those times

made every little miscarriage (being not able to discover their true operations, like smal seeds hid in earthy Darknesse) grow up, and spread into such exuberant branches, that evil Report did often pearch upon them. So dangerous it is for Princes by a Remisse Comportment, to give growth to the least Error; for it often proves as fruitful as Malice can make it. ${ }^{53}$

These events, it was emphasised, had been avoidable. If the King's 'spirit' had 'raised' him up to war when 'the voice of God (the voice of the people) called him to it, happily it might have hindred the great Effusion of Bloud amongst our Selves, that happened after in his Sonnes time'. ${ }^{54}$ What the King had failed to understand was that 'Peace is a great Blessing, if it bring not a Curse with it; but War is more Happy in its effects than it, especially if it takes away the distemper that grows by long surfets, without destroying the Body. ${ }^{55}$

To an extent, such comments simply constitute a rejection of economic statecraft. Wilson showed little interest in discussing James's day-to-day management of commerce, and presented England's colonial successes as achievements of its oppressed people rather than its absolutist monarch. Moreover, there is no sense in the History of Great Britain that commerce might contribute to a nation's military greatness. Rather, wealth is conceived of as a sensuous, feminine form of sickness, and war as its harder, more masculine cure. Despite this, Wilson continued to see the management of finances as critically important. Indeed, the King's inadequacies were, in a sense, economic in character. He had, with disastrous consequences, failed to administer the nation's revenues adequately, and the key event of his reign had been the growth of a new, pernicious form of plenty. 


\section{Royalist history: the writings of William Sanderson}

Direct responses to Weldon's and Wilson's accounts are to be found in the work of the Royalist historian William Sanderson. ${ }^{56}$ Born in 1586, Sanderson was the son of a merchant, also called William. The elder Sanderson enjoyed a highly successful career in trade, acquiring property in England and Ireland, providing funding for the voyages of Martin Frobisher and Walter Raleigh, and becoming a well-known figure in the Elizabethan Court. His son also claimed exalted connections, noting that he had lived a 'long time in Court' and adding, with a nautical flourish, that while he did not "have any hand to the Helm, [he] cabin'd neer the Steerage ${ }^{57}$ His precise activities during the conflicts of the 1640s are not known, but the inscription on his memorial in Westminster Abbey observed that he was famed for 'his family, learning, untainted fidelity to his prince' and noted the 'great hardships [he] sustained under the late tyranny of rebels'. ${ }^{58}$ His reputation, such as it is, rests primarily on his work as a historian. In 1651 he published Aulicus Coquinaria, a point-by-point denunciation of Weldon's Court and Character. He later expanded this pamphlet-length piece into a larger, descriptively titled narrative work: $A$ Compleat History of the lives and reigns of, Mary Queen of Scotland, and of Her Son and Successor, James the Sixth, King of Scotland, and (After Queen Elizabeth) King of Great Britain, France and Ireland (1656). ${ }^{59}$ This account repeated many of his previous comments on Weldon, often copying directly from his earlier discussion, and developed a detailed critique of Wilson's History.

Sanderson's principal argument was that James's reign had been characterised by 'peace and plenty'. ${ }^{60}$ These conditions had brought England considerable advantages: enriching the King's subjects, increasing revenues and raising the nation's reputation internationally. ${ }^{61}$ Moreover, 'trade increased [mightily] by the wise Government of this King'. ${ }^{62}$ Such claims constitute a direct rejection of Weldon's arguments about the poverty of Jacobean England. Equally, however, Sanderson sought to counter the arguments about luxury that had been central to Wilson's work, arguing that

The splendor of the King, Queen, Prince and Princess with the rest of the royall yssue, the concourse of strangers hither from forein Nations, the multitude of our own people from all parts of our three 
Kingdoms gave a wonderfull glory to the Court, at this time, the only Theatre of Majesty; Not any way inferiour to the most Magnificent in Christendom; Prince and people increasing in honor and wealth. ${ }^{63}$

Setting forth this wealth in state, Sanderson continued, with 'all moderate additions of Feasts, Masks, Comedies, Balls and such like' was a 'prudentiall' move. ${ }^{64}$ Such spectacles acted as 'necessary Mirrors, wherein mens Actions are reflected to their own view'. ${ }^{65}$ The objections of Wilson - or as Sanderson labels him, the 'squeazie stomacht Historian' - were a product of his own historical ignorance, and consequent lack of awareness that such practices were 'politickly used in the Romane-Common-wealth and Monarchy' and were judged 'tollerable' in Christian kingdoms and states. ${ }^{66}$ Attention is also drawn to Wilson's own literary background. He was 'bred up a Poet, frequently, a Rymer and Composer of playes', Sanderson observed, and had only turned to history when 'his trade fell to decay' and he was forced to 'trot any way to get money'. ${ }^{67} \mathrm{~A}$ comparison, therefore, is implied between the wealth and glory of the Jacobean Court and the poverty, hypocritical spite and jealousy of its Puritan historian. While such comments constitute a complete rejection of the account of luxury developed in the History of Great Britain, elsewhere in his discussion Sanderson sought to use Wilson's argument about modern corruption against him. In the 'Proeme', which prefaces his account, for example, Sanderson argued that in James's time the kingdom had grown 'aged in happinesse' to the point that

The very excess seemed to abate the pleasure: Or as the hot sent of Musk to some Savors seems to stink. Repetitions of our Blessings then, did not so much affect our Nations as dull them. Peace made us wanton; Plenty intemperate; Mercies secure; Our Benefits then became our Weapons to rebell against his [James's] fame now; The whole Land being sowred by the Peoples Sins; too much felicity introduced Luxury, and Correllaries of Vices, Pride, Ambition, Contempt of things Divine and Human. This Nation in short time sick of a surfeit of Health; afterwards broke with two [sic] much wealth; and now it comes to amendment. Ryot begins to grow thirsty, made so, to go plain; Gluttons to fast; Wantonness, starved into Soberness. ${ }^{68}$

The illness that Sanderson diagnoses here is not, as had been the case in Wilson's account, one of the Court: rather it is one of the people. Indeed, the primary symptom of the nation's sickness, for Sanderson, was the emergence of the sort of gratuitous criticism of the monarchy 
found in the work of Weldon and Wilson. Such claims allowed James to be exonerated of any real crime; he was, in a sense, a victim of his own good government. Equally, however, they ensured that Sanderson was distinctly ambivalent with regard to the 'peace and plenty' which are presented as both James's primary achievement and the causes of the Stuart dynasty's demise.

Ambivalence also characterises Sanderson's attitude to the growing mercantile presence at Court, as can be seen most clearly in his discussions of Ingram and Cranfield. As noted previously, James's critics had made much of these individuals' backgrounds in trade, and portrayed them as lowly and dishonest projectors. In response, Sanderson drew attention to Cranfield's 'antient Family in Gloucestershire' - as demonstrated by 'their bearing of Arms in the Heralds office' - and sought to defend his career in trade. ${ }^{69}$ His rise from merchant adventurer to minister of state was evidence of 'his extraordinary qualities' and the 'blessing of God upon his indeavours' ${ }^{70}$ Moreover, his skills as a merchant were highly useful to the state, giving him 'great understanding in the affairs of the Customes. ${ }^{71}$ As a result, Sanderson asked rhetorically, 'who [was] more fit [...] than this man of experience, in Stating the Accompts, for the Revenues of the State, which [...] he improved, and not unlikely thereby, purchased Envy for his Eminency. ${ }^{72}$ A similar defence is provided of Ingram. At the time of his appointment to the King's household, the 'Customers' [the tax farmers] at the Treasury 'had cozened the King, engrossing by that means, the wealth of Trading'. Because of his own knowledge of trade, however, Ingram could 'and honestly might, discover the cunning craft of the cosening Merchant ${ }^{73}$ This was of particular importance, Sanderson noted, at a time when royal expenditure was rising and revenue was falling.

However, while Sanderson defended Cranfield and Ingram personally, his general assumptions regarding merchants were highly unflattering. These individuals are characterised by their desire to 'cozen' both fellow traders and the nation, and they 'never want will [...] to abuse each other, and [acquire] gain to themselves'. ${ }^{74}$ Mercantile expertise was useful to government because only a merchant could understand and uncover the fundamentally deceitful practices of his fellow tradesmen. James's decision to appoint such individuals, meanwhile, was a product of the dire state of the nation's finances. As Sanderson observed: 
indeed was in this Kings life, the last of that Office [Lord Treasurer], and the meanest of birth, lately altered from the Trust of Nobly-born persons. The Treasury of antient Spring-tides was of late sunck into neap-ebbs of Revenue, and enforced a necessity of providence in collecting, and judgement and practice in disposing: Neither of these could be found by experience suitable to our latern Lord like-breeding, ignorant and careless. ${ }^{75}$

Such comments are used to emphasise the appropriateness of the King's actions for the situation in which he found himself. Equally, however, the fact that individuals such as Cranfield and Ingram were required in government was, for Sanderson, evidence of fundamental problems in the Jacobean Court and Jacobean society more generally.

\section{The Civil War, history and economic statecraft}

At the heart of Civil War era debates concerning James's economic statecraft lay a paradox. Discussions were characterised by new, more combative forms of argumentation. Historians sought not just to represent the people and events of the past, but to actively discredit rival interpretations. The result was a shift not just in the tone of history, but also in its form. Writers either needed to balance chronological narrative with polemic, or reject chronology entirely in favour of a point-by-point denunciation of alternative accounts. Ironically, however, despite the increasingly vituperative nature of such confrontations, the historiographical differences between historians actually narrowed during this period, and a consensus emerged, albeit a broad one, regarding what constituted good economic statecraft. The task of historians, commentators agreed, was to act as judges of the statesmen whose lives they narrated, and to assess whether a particular monarch provided a good or a bad example to posterity. The criteria used to make such assessments were Livian in character. A good monarch, it was assumed, was necessarily a virtuous monarch; a bad monarch was either personally sinful, or lacked the moral authority to counter the influence of his nefarious courtiers. Given the focus on praising or discrediting specific individuals, there was no room for Baconian-style analysis of the relationship between private virtue and vice on the one hand, and the public's interests on the other. Nor was there a place for the broader engagement with issues relating to economic and social change found in the work of Howes. 
With regard to financial issues, the framework was straightforwardly Aristotelian. It was the specific duty of the monarch to manage the nation's financial resources in a manner that demonstrated his liberality. This involved both collecting the right amount of revenue from the right sort of people in the right way, and distributing that revenue in a similarly judicious manner. Commerce, meanwhile, and England's increasing commercialisation were treated with a good deal of suspicion. Indeed, while the accounts of Weldon, Wilson and Sanderson drew on the ideas of honour and dishonour that had underpinned Camden's Annales, their primary concern was not with celebrating honourable trade, but condemning its dishonourable forms. Given such views, the key questions for historians concerned blame. Their task, after making the conventional claims regarding the need for impartiality, was to identify who had caused England's problems and what they had done wrong. While no consensus was to emerge on this issue, it was widely accepted that the nation's difficulties were, in part, financial and commercial in character.

\section{Whig history and political economy: Roger Coke's $A$ Detection of the Court and State of England}

To conclude this chapter, I would like to look at a final account, which in part moves away from the approaches discussed above: Roger Coke's A Detection of the Court and State of England (1694). ${ }^{76}$ After a successful career as a writer on commerce and trade, and a rather less successful career as a businessman, Coke turned to historical writing in the final years of his life. The move appears to have been a profitable one. The Detection, a narrative account of the four Stuart kings and the Protectorate, ran to four editions, the last of which was published in 1719. Coke's conception of historical writing was, in many ways, a conventional one for the period. 'To compose Histories', he noted, paraphrasing the Venetian historian Giovan Battista Nani, 'is sacred, and not to be undertaken but with an upright Mind, and undefiled Hands'. ${ }^{77}$ The sacred quality of history writing, he continued, was a product of the historian's immense power:

taking to himself an absolute Dictatorship, nay an Authority more than Human, over Times, Persons and Actions, governs Fame, measures Deserts, penetrates Intentions, discloses Secrets; is with an 
undistinguished Arbitriment over Kings and People, the Judg of Ages past, and Master of those to come; Absolves or Punishes, Deceives or Instructs. $^{78}$

In exercising this quasi-judicial function, Coke sought to evaluate the achievements of England and its monarchs against a series of Whiggish criteria. His key concern, therefore, was with the degree to which the King and the people, particularly the former, had conformed to the 'Constitutions and Laws of the English Monarchy'. These institutions, Coke observed, 'bave continued for near Nine hundred Years, viz. since King Egbert. ${ }^{79}$ At their heart was the notion that kings could not 'abrogate old Laws, or impose new, or raise Monies from the Subject above the Revenues of the Crown, without Consent in Parliament ${ }^{80}$ When monarchs conformed to the constitution, popular resistance to them is 'High Treason in this World and Damnation in that to come. ${ }^{81}$ However, if kings failed to abide by England's laws and constitutions, then the will of the king and the will of the people came into conflict with one another. ${ }^{82}$ This served to 'distract the Allegiance' of the king's subjects, and give 'Life and Motion to the ambitious Humour of Male-contents'. ${ }^{83}$ The aim of the Detection, Coke asserted, was to show the consequences of the emergence of just such a divided will in 'the Reigns of the Kings of the Scottish Race'. ${ }^{84}$

These ideas directly informed Coke's treatment of James I. His key claim was that the King's violations of the constitution and poor management of the nation's economic interests were interconnected products of his flawed character. James, Coke argued, was an incompetent, lazy and prodigal individual, who showed an unhealthy regard for a series of highly pernicious favourites. To an extent, these traits meant that he neglected his kingly duties. And while he did so, the Dutch 'still grew more powerful at Sea' and Henry IV of France 'was accumulating incredible Treasure at Home, and laying the Foundation of vast Designs Abroad'. ${ }^{85}$ James's crime, however, was not simply inaction. Rather, his incompetence in economic management and his extravagant, debauched lifestyle had led him to adopt a series of unconstitutional approaches to revenue, among them payments for knighthoods, the selling of honours, benevolences and monopolies.

Such ideas are entirely in line with the accounts of Weldon and Wilson. Coke, however, was to develop his analysis a good deal 
further than his predecessors by drawing on the principles that had underpinned the pamphlets on trade that he published in the 1670s, foremost among them $A$ Discourse of Trade (1670) and England's Improvements (1675). ${ }^{86}$ His key claims in these works had been that three particular factors determined the wealth of a nation: convenience of place, numbers of people and free trade. ${ }^{87}$ While England had the best natural resources of any nation, Coke argued, it had failed to increase its population and had introduced a series of measures that restricted commerce, notably monopolies, the apprentice system and the Navigation Acts. In the Discourse and England's Improvements Coke had offered a systematic analysis of England's errors with regard to economic policy based around a series of theorems and propositions. The Detection essentially transformed this material into a chronological narrative, outlining the specific actions that England's monarchs had performed with regard to commerce and finance, and assessing their effectiveness.

In relation to James I, Coke's most detailed discussion of commercial affairs concerned monopolies, a theme he returned to repeatedly. His approach to the issue is distinctive. He is not so much concerned with the reasons why James set up monopolistic trading companies or the events and debates surrounding their establishment. Rather, as can be seen particularly clearly in his discussion of the monopoly on Spanish trade established in 1604, his account departs from conventional historical analysis entirely and provides a long list of arguments in favour of free trade, derived in part from the Discourse on Trade. Coke's assertion was that people's subsistence is naturally dependent on the assistance of others and their own labour. Monopolies, he contended, by excluding individuals from certain trades, deprive people of the assistance and labour they naturally require to live and, therefore, violate the law of nature. This violation, Coke continued, was worse than the tyranny that the Pharaohs exercised over the Israelites; whereas the Egyptians imposed 'a greater Hardship how to live' by compelling the Israelites to make bricks yet denying them straw, monopolies deny 'poor Men their Means of living'.$^{88}$ In addition to this, monopolies, by restraining the 'Labours and Industry of Men in any Profession, Art or Mystery', not only hinder their improvement in a particular country, but provide a way for rival nations to enlarge their own manufactures. ${ }^{89}$ After outlining these issues at length, Coke concluded by noting that 'we have 
thought fit to premise this, that a better View may be had of what follows' ${ }^{90}$

The discussion that follows is essentially a brief account of the end of the monopoly, by means of a 'memorable Law' passed by Parliament. ${ }^{91}$ To an extent, Coke's account here is conventionally Whiggish in its desire to attribute any positive developments that took place in Jacobean England to Parliament rather than the King. What is noteworthy, however, is that his argument marks a substantial departure from those of James's other critics. As we have seen, Weldon conceived of James's reign as a time of poverty, while Wilson saw it as dominated by a corrupt and debauched form of plenty. Coke disagreed, arguing that 'tho the King was never poorer than at this time', free trade with Spain ensured that 'the Nation was far richer than in all the long Reign of Queen Elizabeth'. ${ }^{92}$ Such comments, coupled with Coke's opposition - on commercial grounds - to war with Spain, provide an important hint as to his priorities. He was, it would seem, rather more interested in defending what he conceived of as England's trading interests than he was in advancing conventional pro-Whiggish or anti-Stuart arguments.

To an extent, Coke's account provides a demonstration of the difficulties of blending political economy with narrative history. In showing how James had failed to understand the basic principles of commerce, Coke was obliged to offer lengthy summaries of those principles himself. As a result, the narrative tended to stop at the point where the economic analysis began. At the end of the Detection, meanwhile, Coke abandoned narrative altogether, and expressed his argument in a numbered list of twenty-three commercial policy recommendations. Consequently, his work functions as a useful example of a historical account that puts commerce at its heart; indeed, the Detection is built on the idea that 'the Riches of England' and its 'Strength and Glory' are 'derived from our Foreign Trades'. ${ }^{93}$ In this sense, therefore, concerns regarding commercialisation, which had been a key feature of the work of Civil War era historians, are entirely absent from the Detection. When discussing economic issues, however, Coke does not reject conventional assumptions regarding history's didactic function. His account of the Act that ended the Spanish monopoly, for example, concluded by noting that 'the Reasons in this Act extend to all other Beneficial Trades, as to Turkey, the East-Country and Hamburgh Trades, and to Africa 
and the East-Indies. ${ }^{94}$ Implicit in this statement was the suggestion that action against monopolies was required from modern statesmen. Coke also stressed that his motivation for writing the Detection was rooted in his concern for England's economic interests. He had taken up his pen to convince the various orders of society - listed as nobility, gentry, clergy and merchants - that 'the Employment of People, and the Freedom of Trade, be the two great Principles of the flourishing and happy State of any Country. ${ }^{95}$

Writing in the conclusion to the Detection, Coke observed that 'I have done, and I do not know but I am the first that ever begun a Work of this Nature. ${ }^{96}$ This claim, while a bold one, is entirely justified; no other history of the period had attempted to blend political economy with history in quite this manner. It might be added that no other work was ever to attempt it again, and there is undoubtedly a sense in which Coke's approach represents a historiographical dead end. Nevertheless, as we shall see in the next chapter, his ideas helped, in part, to set the agenda for the most successful historian of the first half of the eighteenth century: Paul de Rapin de Thoyras. 